\title{
Government planning in Brazilian municipalities: towards a research agenda
}

\author{
LUCIANA LEITE LIMA ${ }^{1}$ \\ LIZANDRO LUI ${ }^{2}$ \\ GianNa Vargas Reis Salgado Dias ${ }^{1}$ \\ LUCIANA PAZINI PAPI ${ }^{3}$ \\ DIOGO JOEL DEMARCO ${ }^{3}$
}

${ }^{1}$ Universidade Federal do Rio Grande do Sul (UFRgS) / Programa de Pós-graduação em Políticas Públicas, Porto Alegre - RS, Brazil

${ }^{2}$ INSTITUTO dE PESQUisa ECONÔMICA APLICAda (IPEA), BRASÍLIA - DF, BRAZIL

${ }^{3}$ Universidade federal do Rio Grande do Sul (UfrgS) / Escola de Administração, Porto Alegre - RS, Brazil

\begin{abstract}
Brazil's Constitution of 1988 gave municipalities the status of autonomous federated entities. They were assigned a series of responsibilities in the field of public policies, including the duty of preparing government plans. Before the constitution, planning and the state capability regarding this task were concentrated in the federal bureaucracy. In this institutional and organizational changing scenario, the objective of this article was to investigate the scientific production regarding municipal planning. A systematized search of articles was carried out on the Portal Periódicos Capes databases for the period 1995 to 2018. The results showed that the field is incipient, lacking theoretical and analytical regularity, privileges a normative bias, and is strongly based on approaches developed in the field of business administration. This study corroborates the relevance of this research agenda. It stresses the importance of local management for the federation and the protection of rights.
\end{abstract}

Keywords: Government Planning. Municipality. Decentralization. State Capacities. Public Policies.

\section{Planejamento governamental nos municípios brasileiros: em direção a uma agenda de pesquisa}

\section{Resumo}

A Constituição Federal de 1988 alçou os municípios à condição de entes federados autônomos, atribuiu-lhes uma série de competências em relação às políticas públicas e descentralizou a responsabilidade pela confecção de peças de planejamento governamental. Até então, este tipo de atividade, bem como as capacidades estatais correspondentes estavam concentrados na burocracia federal. Neste cenário de mudança institucional e organizacional, o objetivo deste artigo foi investigar a produção científica sobre o planejamento municipal. Para isso, realizamos uma busca sistematizada de artigos nas bases do Portal Periódicos Capes abrangendo o período de 1995 a 2018 . Os resultados evidenciaram que o campo é incipiente, carecendo de regularidade teórica e analítica, privilegia um viés normativo e está fortemente alicerçado em abordagens da administração de organizações privadas. Com isso, sustentamos a pertinência desta agenda de pesquisa, em consonância com a importância da gestão local para a federação e para a garantia de direitos.

Palavras-chave: Planejamento Governamental. Município. Descentralização. Capacidades Estatais. Políticas Públicas.

\section{Planificación gubernamental en los municipios brasileños: hacia una agenda de investigación}

\section{Resumen}

La Constitución de 1988 elevó a los municipios a la condición de entes federados autónomos, les atribuyó una serie de competencias en el campo de las políticas públicas, y descentralizó la responsabilidad por la confección de la planificación gubernamental. Hasta entonces, este tipo de actividad, así como las capacidades correspondientes de los estados estaban concentrados en la burocracia federal. En este escenario institucional y organizativo cambiante, el objetivo de este artículo fue investigar la producción científica sobre la planificación municipal. Para ello, realizamos una búsqueda sistematizada de artículos en las bases del Portal Periódicos Capes que abarcó el período de 1995 a 2018 . Los resultados evidenciaron que el campo es incipiente, carece de regularidad teórica y analítica, privilegia un sesgo normativo y está fuertemente basado en enfoques de la administración de organizaciones privadas. Con ello, sostenemos la pertinencia de esta agenda de investigación, en consonancia con la importancia de la gestión local para la federación y para la garantía de derechos.

Palabras clave: Planificación gubernamental. Municipio. Descentralización. Capacidades de los estados. Políticas públicas. 


\section{INTRODUCTION}

For over a century, Brazil has been a federation. It was only in 1988, however, that the federal constitution established the Brazilian states and municipalities as federated entities. After that, a series of political and institutional changes took place; among them, an intense process of decentralization of public policies. The municipalities received the attribution to carry out health, education, social assistance, culture, and basic sanitation policies, which until then were the responsibility of agencies subordinated to the central government. Concomitantly, the local governments were tasked with budget and planning, such as producing multi-year plans, master plans, and following the budget guidelines law (LDO).

However, Brazilian municipalities have different conditions to meet constitutional requirements. Many of them show low socioeconomic development and struggle with bureaucratic and administrative precariousness (GRIN, 2014; MARENCO and STROHSCHOEN, 2018). Also, the history of modern management structures focusing on planning is recent in most Brazilian municipalities, which is mostly a result of the past legacy of centralization of this attribution with the Union. Thus, until 1988, government planning, sometimes intense and at other times scarce, was concentrated in federal agencies responsible for the elaboration of plans and projects usually focused on economic growth (CARDOSO JUNIOR, 2011).

This article contributes to strengthen and develop the research agenda on the Brazilian local government's management. The study observes that municipalities are not familiar with planning activities, and assumes that local governments lack state capacities to perform them - considering the history of centralization in the country. Therefore, it is crucial to understand how municipalities are managing their attributions in this context, recognizing that planning activities are essential for the expansion and quality of processes of public policy formulation and implementation. Against this backdrop, the objective of this article is to investigate government planning in Brazilian municipalities, their processes, and conditions. Planning will be approached in its most comprehensive conception to include all activities of a government, intermediate and final, as well as sectoral policies and administrative activities. The focus is on Brazilian scientific articles written on the subject since the early 1990s. This is a qualitative research of exploratory and descriptive nature, using secondary data.

The article is organized into four parts, in addition to the introduction and conclusion. In the first section, we discuss the history of government planning in Brazil until the first decade of the 2000s, focusing on its logic and contexts. The second part focuses on the municipalities, highlighting their state characteristics and capacities for planning. In the third section, we present the methodological procedures, and the fourth shows the discussion of the research results.

\section{HISTORY OF GOVERNMENT PLANNING IN BRAZIL}

Government planning as a tool for projecting and modeling the future has been used in public administration, particularly since the 19th century. At that time, governments, both in central and peripheral countries, started to apply it as a way to promote economic and social development. However, after the First World War, planning became a strategic asset, related to leveraging profound changes in societies. This was the case of the Soviet Union, which from 1920 undertook systematic efforts to convert its feudal society into an industrialized one, as well as the United States, after the great crisis of 1929; and from Europe, in the post-World War II reconstruction process. The practice of governmental planning, in all these contexts, was centralized in the state, i.e., the central governments were the protagonists of the dynamics of elaboration and implementation. The same characteristics were present in the case of Brazil.

Government planning in Brazil has shown oscillation between moments of appreciation and little attention. There were two notable periods of decline and two peaks, alternately: decline from 1889 to 1930, peak in the middle of 1930 to 1970, decline from 1980 to 1990, and peak from the first half of the 2000s (CARDOSO JUNIOR, 2011; REZENDE, 2011). The first period was marked by sparse and sectoral state actions, aimed at managing moments of crisis. Planning was not, therefore, something considered strategic or broad (CARDOSO JUNIOR, 2011).

In the second period, comprehensive planning actions gained space from the 1930s, led by the central government. The actions focused on the objectives of that time: to guarantee greater autonomy of the Brazilian economy in relation to the foreign economy, and promote industrialization (REZENDE, 2011). State agencies were created, such as the Administrative Department of the Public Service, which formulated the first Brazilian five-year plan, the Special Plan for Public Works and 
National Defense Equipment (1939-1943), and the Works and Equipment Plan (REZENDE, 2011). In the 1940s, the development of planning followed an upward course with the creation of the first Brazilian state-owned companies: Companhia Vale do Rio Doce, Petróleo Brasileiro S/A, Centrais Elétricas Brasileiras, and the National Bank for Economic Development. In 1946, the Salte Plan (1946) was launched (but not implemented), pointing out priority areas for state action (CARDOSO JUNIOR, 2011; REZENDE, 2011).

Between the 1950s and 1970s, government planning was more intense, and it was adopted by both democratic governments and the civil-military dictatorship. It was, at first, intensively practiced and had a discretionary nature. The peak of government planning in this period was achieved due to the efforts of the Economic Commission for the Caribbean and Latin America (ECLAC) in disseminating developmentalist practices regardless of democratic or dictatorial governments. In Brazil, developmentalism was expressed in the Plan of Goals designed during the government of President Juscelino Kubitschek. In the subsequent politically troubled governments of President Jânio Quadros, who resigned, and his substitute President João Goulart, government planning found no fertile ground to advance. The Triennial Economic and Social Development Plan was an unsuccessful attempt to implement government planning during this period. It failed due to the lack of support from the federal legislative branch (CARDOSO JUNIOR, 2011; REZENDE, 2011).

From 1964 until the end of the 1970s, government planning actions intensified, marked by an authoritarian-technocratic and vertical bias. They formed instruments for carrying out the great administrative reform of the state in $1967^{1}$, through the implementation of the Government's Economic Action Plan and the creation of three National Development Plans (CARDOSO JUNIOR, 2011). It is worth noting that the neoliberal ideology started to spread worldwide during the mid-1970s, and its impact was felt in the following decades. The political-administrative characteristic of this set of ideas, which focus on government management, was based on an essentially negative view of the state and its activities (EVANS, 2004). As a result, government planning structures and institutions began to crumble, and the few practices were concentrated on short-term initiatives aimed at controlling what was treated, for decades, as the country's central social problem: inflation (CARDOSO JUNIOR, 2011). Regarding planning at the state level, Saddi (2003) points out that President Geisel's government created a Technical Cooperation Program, carried out between 1974-1978, with the initial objective of institutionalizing state planning systems and minimizing fiscal problems. The technical cooperation relationship with the municipalities, on the other hand, was the state government's responsibility.

The 1980s were marked by a paradox. The assumption of the collapse of the authoritarian government promoted and strengthened the struggle for democracy and the welfare state. However, the world's intellectual environment was stimulated by neoliberal ideas about the state's operation. In this scenario, the 1988 Federal Constitution made planning a mandatory activity of governments, emphasizing the short and medium-term perspectives and linked to the budget. According to Cardoso Junior (2011), the act of planning formally became part of the daily practices of public administration and ideally working as a connection between succeeding governments, creating a convergence between democratic alternation and stable public administration.

Between 2000 and 2010, government planning intensified with the implementation of Multi-Year Plans (PPA) in the Union, states, and municipalities, with the creation of planning departments such as the Secretariat for Strategic Affairs of the Presidency of the Republic. Also, the federal government designed and implemented two programs to increase public investment in urban, social, logistics, and energy infrastructure, known as Growth Acceleration Programs (2007 and 2011). In 2010, the Secretariat for Strategic Affairs of the Presidency of the Republic formulated a long-term plan for the generation of economic and social development. The plan was not implemented, but established goals for various sectors, such as infrastructure, public security, health, education, agriculture, state administration, international relations, public transparency, and the tax system (CARDOSO JUNIOR, 2011).

This brief explanation of the history of government planning in Brazil shows that the central government played a predominant role. The criticisms about such centralization of state planning capacities focused on its dysfunctions (CARDOSO JUNIOR and SANTOS, 2018) and its organizational incompleteness as a system (COUTO and MAGALHÃES, 2017).

\footnotetext{
${ }^{1}$ The federal reform was established by Decree-Law 200 of February 25, 1967 (BRASIL, 1966).
} 
This study suggests that one of the consequences of the federal government centrality was the little attention of academic research regarding government planning in Brazilian municipalities and states, which reflects the marginal roles these entities played in the development of the federation over time. In the case of municipalities, as they gained autonomy relatively later, the lack of planning instruments is even more acute. Noll and Marenco $(2018$, p. 19) argue that "[...] the status acquired by local governments translated into greater political-legal autonomy" in a context of decentralization informed by a denial of the extreme political centralization experienced in the recent authoritarian regime.

Starting from the transformations introduced by the Constitution, the next section explores the heterogeneity, the new attributions, and state capacities that have an impact on the municipalities' planning activities.

\section{BRAZILIAN MUNICIPALITIES AND PLANNING: CONTEXT, LIMITS, AND POTENTIAL}

The 1988 Federal Constitution brought about a set of political and institutional changes in Brazil. As for the distribution of power across the territory, the constitution established a federative model with three autonomous and interdependent federated entities: Union, states, and municipalities. The model resulted from the combination of decentralizing democratic forces and traditional groups and elites who, at the time of re-democratization, took advantage of the weakening federal administration to defend an agenda for strengthening subnational governments (ABRUCIO, 2005; ALMEIDA, 2005; FALLETI, 2006; GIBSON and FALLETI, 2007; GOULART, 2013).

The decentralization process towards subnational entities has been widely discussed over the past decades (ARRETCHE, 1999, 2012; ARRETCHE and MARQUES, 2002; CAVALCANTE, 2011; DOWBOR, 2015; DUARTE, PESSOTO, GUIMARÃES et al., 2015; FREITAS, 2015; LIMA, QUEIROZ, MACHADO et al., 2012; SÁTYRO, CUNHA and CAMPOS, 2016; SOUZA, 1998). The literature shows that decentralization (be it in planning or in the implementation of public policies) increased in certain fields of public policy such as health, the environment, social assistance, and education. However, Souza (2004) points out that the new system of local governance, in which the municipalities assumed responsibility for the implementation of a wide range of public policies, materialized in unevenly among Brazilian municipalities, and its sustainability is still unclear. As for fiscal, legislation, and tax issues, they are still predominantly allocated to the central government. Municipalities are responsible for their own fiscal management and local tax collection, although most of them are highly dependent on constitutional transfers from states and the Union (FIRJAN, 2018).

The literature indicates that decentralization has accentuated the extreme inequality of political, technical, and financial conditions in Brazilian municipalities, making the process highly intricate and heterogeneous. In this sense, some studies sought to understand the efforts of the central government in promoting channels of inter-federative cooperation and the training of local governments in order to comply with constitutional determinations (GRIN, 2014; GRIN and ABRUCIO, 2017).

One of the innovations of the 1988 Federal Constitution was the obligation to create new budget planning and control instruments for all federal entities - hitherto restricted to the Union and the states. The constitution defined that all entities must prepare the Annual Budget Law (LOA), the LDO, in addition to the Multi-Year Plan (PPA). Thus, all expenses, investments, and financial actions must be included in these plans.

In the last decades, for example, the elaboration of sectoral planning instruments gained significant relevance for Brazilian municipalities, since both Law 11445/2007 (BRASIL, 2007) - known as the Basic Sanitation Law - and Law 12305/2010 (BRASIL, 2010), which institutes the National Solid Waste Policy (PNRS), established that municipalities had to prepare their respective municipal plans. Both laws made it mandatory to prepare such plans in order to receive funds from the Union to implement policies on sanitation and waste management. In addition, municipalities with more than 20 thousand inhabitants must prepare a master plan, which provides for the subdivision and use of urban land, among other provisions - as stated by Law 10257/2001 (BRASIL, 2001). Thus, in addition to PPA, LDO, and LOA, municipalities also needed to prepare a wide range of sector plans.

Concomitantly with this process of assuming responsibilities for public policies, the number of municipalities in Brazil has grown since 1980 from 3,974 to 5,570 in 2010 (TOMIO, 2002, 2005). Table 1 shows that the majority of municipalities are small: $44 \%$ have up to 10,000 inhabitants and $68 \%$, up to 20,000 inhabitants (IBGE/MUNIC, 2015). 
Table 1

Number of municipalities in Brazil and population

\begin{tabular}{c|c|c}
\hline Population & Number of municipalities & $\%$ \\
\hline Up to 5,000 & 1,237 & $22.21 \%$ \\
5,001 to 10,000 & 1,214 & $21.80 \%$ \\
10,001 to 20,000 & 1,377 & $24.72 \%$ \\
20,001 to 50,000 & 1,087 & $19.52 \%$ \\
50,001 to 100,000 & 353 & $6.34 \%$ \\
100,001 to 500,000 & 261 & $4.69 \%$ \\
More than 500,000 & 41 & $0.74 \%$ \\
Total & 5,570 & $100 \%$ \\
\hline
\end{tabular}

Source: IGBE/MUNIC (2015).

Regarding planning capacity, IBGE/MUNIC (2015) shows that $75 \%$ of Brazilian municipalities present an administrative structure focused on urban planning ${ }^{2}$. Table 2 shows that practically all the municipalities with more than 100 thousand inhabitants have a technical structure focused on this activity. It is noteworthy that $38 \%$ of the municipalities with less than 5,000 inhabitants and $32 \%$ of those with less than 10,000 inhabitants do not have this specific structure.

Table 2

Municipalities and local organizational structure for urban planning

\begin{tabular}{c|c|c|c|c}
\hline Population & $\begin{array}{c}\text { With } \\
\text { structure }\end{array}$ & $\%$ & $\begin{array}{c}\text { Without } \\
\text { structure }\end{array}$ & $\%$ \\
\hline Brazil & 4,192 & 75.26 & 1,378 & 24.74 \\
\hline Up to 5,000 & 764 & 61.76 & 473 & 38.24 \\
\hline 5,001 to 10,000 & 820 & 67.55 & 394 & 32.45 \\
\hline 10,001 to 20,000 & 1,049 & 76.18 & 327 & 23.75 \\
\hline 20,001 to 50,000 & 929 & 85.46 & 158 & 14.54 \\
\hline 50,001 to 100,000 & 331 & 93.77 & 22 & 6.23 \\
\hline 100,001 to 500,000 & 257 & 98.47 & 4 & 1.53 \\
\hline More than 500,000 & 41 & 100 & 0 & 0,00 \\
\hline
\end{tabular}

Source: IBGE/MUNIC (2015).

In addition, IBGE/MUNIC data do not include other structures focused on planning, such as those specific to the preparation of the PPA, which is more comprehensive because it aggregates all sectoral policies and administrative (intermediary) activities. The research focuses on mapping structures established to prepare the municipalities' master plan. It should be noted that urban planning is an activity linked to the administration of the municipality, thus integrating sectoral policy. Regarding comprehensive planning, some studies indicate great technical and administrative shortages, especially in small municipalities, which end up hiring consultants for the preparation of the PPA (AZEVEDO and AQUINO, 2016; MARINHO and JORGE, 2015).

In addition, the Brazilian municipalities' dependence on constitutional transfers is striking, a process that can compromise municipal autonomy. According to the Industry Federation of the State of Rio de Janeiro (2018), three decades after the

\footnotetext{
${ }^{2}$ The Brazilian Institute of Geography and Statistics (IBGE) adopts the following typology to characterize the concept 'urban planning structure': "exclusive municipal secretariat," "municipal secretariat responsible for urban planning and other policies," "urban planning is handled by a department in another secretariat," "department under the direct order of the executive office," "agency of the indirect administration," and "does not present a specific structure."
} 
promulgation of the federal constitution, the financial situation of the municipalities was unbalanced in the volume of revenue and in the generation of their own collection: $81.7 \%$ of the municipalities did not generate even $20 \%$ of their revenue. In addition, the smaller the municipality, the greater the dependence on federal transfers. Grin (2014) points out that the decentralization of responsibilities for the formulation and implementation of public policies has not been accompanied by the expansion of tax collection and technical-administrative capacities.

In this debate, it is necessary to include information about the professionalization of municipal bureaucracies. Data from the Basic Information Survey (IBGE/MUNIC, 2011) showed that $40 \%$ of the civil servants in Brazilian municipalities have a highschool education, $23 \%$, elementary education, and $28 \%$ higher education. In addition, $7 \%$ are graduate students, and $2 \%$ have no formal education. In other words, the majority of civil servants in municipalities did not have higher education, which can affect administrative capacity.

Therefore, it is evident the importance and constraints of the municipalities in the current scenario. On the one hand, they have the status of federated entities and are tasked with developing plans and instruments to guide the implementation of public policies in their territories. On the other hand, they are highly heterogeneous, unequal, and have limited capacities to implement public policies. This scenario led to several initiatives to qualify local managers, particularly to build multi-year plans (PPAs). Two examples are the efforts of the National School of Public Administration (ENAP) and the Brazilian Institute of Municipal Administration (IBAM).

Finally, both the numerous studies on planning at the level of the central government (CARDOSO JUNIOR, 2011), and, in contrast, the little attention of academia to the issue of planning at the municipal level stand out. This article does not tackle sectoral planning, related to specific policies on health, the environment, or education, for instance. The study contributes to the literature by focusing on the comprehensive planning activity of municipalities.

\section{METHODOLOGY}

The study consisted of a systematic search of articles in the database of the Portal Periódicos Capes, which includes journals indexed in the Scientific Electronic Library Online (SCIELO). This source guarantees access to articles published in the main national journals. The terms "municípios" (municipalities) and "planejamento" (planning) were used in the search for peerreviewed articles, based on original empirical research (essays and literature reviews were excluded), in Portuguese throughout the text (including title, abstract and subject), from 1995 to 2018. This search was carried out in June 2018. The scoping review method was adopted to search and organize the studies, inspired by the works by Levac, Colquhoun, and O'Brien (2010) and Schaefer, Barbiani, Nora, et al. (2018). According to the authors, the scoping review method is used when the objective is mapping relevant studies in the field of interest and evaluate their content.

However, this method does not consider non-indexed works such as theses, dissertations, book chapters, or materials published by institutions such as the Konrad Adenauer Foundation, the Institute of Applied Economic Research, and the Inter-American Development Bank. On the other hand, the scoping review provides greater control over the quality of the analyzed publications, since it considers only articles published in peer-reviewed journals, indexed on consolidated bases in the academic environment.

The search resulted in 1,685 articles, which were analyzed to be included in the study according to the following criteria: primary research, published in full, the objective was to examine the governmental planning process, in a comprehensive and non-sectorial sense, at the municipal level in Brazil. The criteria for excluding articles from the sample were: essays or theoretical reviews, discussion of governmental planning within the scope of the Union or states of the federation, research on sectoral governmental planning (restricted to the scope of specific public policies). This analysis was conducted by two researchers independently, and a final review was carried out by a third researcher.

The researchers read the title and the abstract of the retrieved 1,685 publications and found that despite a large number of articles, most of them focused on topics such as family planning and health actions, environmental planning, tourism planning, and action planning conducted at the federal level. After this exhaustive review, 160 studies addressed the theme of municipal planning in Brazil. The content of the 160 articles was then carefully evaluated, and the majority of them (154) 
discussed sectorial policies, which was out of the criteria to form the sample. Therefore, the analysis selected six articles that fit the defined criteria.

Because of the reduced number of articles, the researchers analyzed the abstracts of articles published in the journals Revista Planejamento e Políticas Públicas, Revista de Administração Pública, Revista do Serviço Público, and Cadernos EBAPE.BR. Two further articles fit the defined criteria and were selected from this consultation. Therefore, the final sample was composed of eight articles.

\section{RESULTS AND DISCUSSION}

The search revealed many studies on planning applied to public policy sectors, such as health, education, and the environment, which is a consequence of multiple factors, including the rise of pluralistic and fragmented perspectives as a result of comprehensive approaches that emerged in the 1970s. In Brazil, the increase and consolidation of rights from the 1988 Federal Constitution, associated with the federative design (Union, states, municipalities), catalyzed the interest and demand for specific technical knowledge linked to the peculiarities of each sector of public policy. This brings attention to ways of integrating these heterogeneous policies into more general planning, as intended by the PPA, for example.

These dynamics are reflected in eight articles, selected based on their focus (or study object) on comprehensive government planning at the municipal level (Box 1).

\section{Box 1}

\section{Selected articles and Capes classification}

\begin{tabular}{|c|c|c|c|c|c|}
\hline \multirow{2}{*}{ Authors } & \multirow{2}{*}{ Title } & \multicolumn{3}{|c|}{ Journal details } & \multirow{2}{*}{ Qualis* } \\
\hline & & Name & State & Year & \\
\hline Souza & $\begin{array}{l}\text { Avaliação do processo de implantação de um plano estratégico participativo } \\
\text { municipal: um estudo de caso [Evaluation of the implementation of a municipality's } \\
\text { participatory strategic plan: a case study] }\end{array}$ & $\begin{array}{c}\text { Revista de } \\
\text { Estudos Sociais }\end{array}$ & MT & 1999 & B3 \\
\hline $\begin{array}{l}\text { Oliveira, } \\
\text { Oliveira, } \\
\text { Siqueira and } \\
\text { Brito }\end{array}$ & $\begin{array}{l}\text { Inovação gerencial em municípios: análise exploratória das práticas de gestão } \\
\text { do plano estratégico de Juiz de Fora [Managerial innovation in municipalities: } \\
\text { exploratory analysis of managerial practices in the strategic plan of Juiz de Fora] }\end{array}$ & $\begin{array}{l}\text { Cadernos } \\
\text { EBAPE.BR }\end{array}$ & SP & 2006 & $\mathrm{~A} 2$ \\
\hline Rezende & $\begin{array}{l}\text { Integração do Plano Plurianual Municipal e o Planejamento Estratégico Municipal: } \\
\text { proposta e experiência de um município paranaense [Integration of multi-year } \\
\text { plan and strategic planning: the experience of a municipality in the state of } \\
\text { Paraná and proposals] }\end{array}$ & Redes & $\mathrm{RS}$ & 2010 & B3 \\
\hline $\begin{array}{l}\text { Leite and } \\
\text { Rezende }\end{array}$ & $\begin{array}{l}\text { Modelo de gestão municipal baseado na utilização estratégica de recursos da } \\
\text { tecnologia da informação para a gestão governamental: formatação do modelo } \\
\text { e avaliação em um municipio [Managerial model for local governments, based on } \\
\text { the use of IT in public administration: modeling and evaluation in a municipality] }\end{array}$ & $\begin{array}{l}\text { Revista de } \\
\text { Administração } \\
\text { Pública- RAP }\end{array}$ & RJ & 2010 & A2 \\
\hline $\begin{array}{l}\text { Marinho and } \\
\text { Jorge }\end{array}$ & $\begin{array}{l}\text { O planejamento local é mais eficiente? Uma análise de } 14 \text { municipios } \\
\text { sergipanos de pequeno porte [Is local planning more efficient? } \\
\text { An analysis in } 14 \text { small municipalities in the State of Sergipe] }\end{array}$ & Nova Economia & MG & 2015 & B1 \\
\hline $\begin{array}{l}\text { Ritter and } \\
\text { Grasel }\end{array}$ & $\begin{array}{l}\text { Estratégias para a busca da Gestão de Excelência: um estudo } \\
\text { de caso no município de Canarana [Strategies to management } \\
\text { excellence: a case study in the municipality of Canarana] }\end{array}$ & $\begin{array}{c}\text { Revista de } \\
\text { Estudos Sociais }\end{array}$ & MT & 2016 & B3 \\
\hline Ferreira Filho & $\begin{array}{l}\text { A Importância do Plano Plurianual Participativo na Gestão Pública } \\
\text { [The importance of participatory multi-year plan in public management] }\end{array}$ & $\begin{array}{l}\text { Revista } \\
\text { Controle }\end{array}$ & CE & 2016 & B4 \\
\hline $\begin{array}{l}\text { Azevedo and } \\
\text { Aquino }\end{array}$ & $\begin{array}{l}\text { O planejamento em municipios de pequeno porte em São Paulo } \\
\text { [Planning in small municipalities in the State of São Paulo] }\end{array}$ & \begin{tabular}{|} 
Revista de \\
Contabilidade e \\
Organizações
\end{tabular} & SP & 2016 & $\mathrm{~A} 2$ \\
\hline
\end{tabular}

Source: Elaborated by the authors.

* Qualis Capes is a classification of scientific journals adopted in Brazil. The classification of the journals examined in the research refers to the period 2013-2016, in the area of Public and Business Administration, Accounting and Tourism. 
As observed in Box 1, the studies are distributed over a period of almost twenty years. The fact that they seem sparse throughout the period suggests a limitation in the incorporation of this object of study by academia, despite its social relevance. Box 1 also shows no repetition of authors, except Rezende, who appears in two propositional articles. This phenomenon indicates a non-persistent and little institutionalized production.

The journals are distributed in four regions of Brazil, and half of them are included in the first strata of the Qualis Capes classification. The themes of interest of the journals include external control, regional development, administration, and economics, with a prevalence of the last two. Therefore, the studies fall into the field of applied social sciences, backed by the areas that traditionally value and develop the topic of 'planning.' The research also looked at the areas of qualification of the fourteen listed authors. It was found that six authors were trained in the areas of administration and accounting, three in economics, two in production engineering, and the rest in social sciences, information sciences, sociology and anthropology, and urban management.

Box 2 shows some elements of the articles' structure and content.

Box 2

Nature, method, and theoretical framework of the selected articles

\begin{tabular}{|c|c|c|c|}
\hline Article & Nature & Method & $\begin{array}{c}\text { Theoretical } \\
\text { Framework }\end{array}$ \\
\hline Souza (1999) & evaluative & case study & Yes \\
\hline $\begin{array}{c}\text { Oliveira, Oliveira, } \\
\text { Siqueira et al. (2006) }\end{array}$ & descriptive & case study & Yes \\
\hline Rezende (2010) & $\begin{array}{c}\text { exploratory, descriptive, } \\
\text { propositional }\end{array}$ & case study & Yes \\
\hline Leite and Rezende (2010) & propositional & case study & Yes \\
\hline Marinho and Jorge (2015) & descriptive & multiple case \\
studies & Yes \\
\hline Ritter and Grasel (2016) & exploratory, propositional & case study & Yes \\
\hline Ferreira Filho (2016) & advocacy & - & No \\
\hline Azevedo and Aquino (2016) & descriptive & Survey & Yes \\
\hline
\end{tabular}

Source: Elaborated by the authors.

Box 2 shows that exploratory, descriptive, and propositional studies are the most common. Except for those who proposed or advocated specific planning methodologies, the others focused on the processes for preparing plans. It is possible to say that the field of study is incipient since the research has not yet progressed to studies involving the discovery of causal relationships. Little is known about the social dynamics in Brazilian municipalities and about the contribution of planning to local management.

Box 3 shows that the case study was the most used method, and the studies focused more often on small municipalities. The articles start from the hypothesis that the lack of resources in small municipalities represents a limitation in their planning capacity. 
Box 3

Municipalities studied in the selected articles

\begin{tabular}{|c|c|c|}
\hline Article & Municipality & $\begin{array}{c}\text { Estimated } \\
\text { population }(2018)^{*}\end{array}$ \\
\hline Souza (1999) & Doutor Pedrinho (SC) & 4.013 \\
\hline Oliveira, Oliveira, Siqueira et al. (2006) & Juiz de Fora (MG) & 564.310 \\
\hline Rezende (2010) & Not informed & - \\
\hline Leite and Rezende (2010) & Curitiba & 1.917 .185 \\
\hline Marinho and Jorge (2015) & $\begin{array}{c}14 \text { small municipalities in Sergipe } \\
\text { (up to } 20,000 \text { inhabitants) }\end{array}$ & - \\
\hline Ritter and Grasel (2016) & Canarana (MT) (small municipality) & 21.311 \\
\hline Ferreira Filho (2016) & - & - \\
\hline Azevedo and Aquino (2016) & $\begin{array}{l}65 \text { municipalities in São Paulo } \\
\text { (up to 50,000 inhabitants) }\end{array}$ & - \\
\hline
\end{tabular}

Source: Elaborated by the authors.

*Based on data from IBGE (2015)

The research examined the theoretical framework used in the studies selected. One of them did not have a theoretical framework, and the author adopts a normative approach based on laws and regulations that guide the PPA and the participatory PPA. Box 4 presents the theoretical framework adopted in the selected articles.

Box 4

Theoretical and conceptual framework of the selected articles and whether the studies present the context of planning in Brazil

\begin{tabular}{|c|c|c|}
\hline Article & Theoretical framework & $\begin{array}{c}\text { Context of planning } \\
\text { in Brazilian } \\
\text { municipalities }\end{array}$ \\
\hline Souza (1999) & Planning: strategic, municipal, participatory, and social & yes \\
\hline $\begin{array}{c}\text { Oliveira, Oliveira, } \\
\text { Siqueira et al. (2006) }\end{array}$ & Public planning, urban planning, and municipal strategic plan & yes \\
\hline Rezende (2010) & Municipal strategic plan & yes \\
\hline Leite and Rezende (2010) & Business intelligence, balanced scorecard, customer relationship & no \\
\hline Marinho and Jorge (2015) & Municipal planning & no \\
\hline Ritter and Grasel (2016) & Strategic planning, municipal strategic plan, situational strategic plan & no \\
\hline $\begin{array}{c}\text { Ferreira Filho (2016) } \\
\begin{array}{c}\text { Azevedo and Aquino } \\
\text { (2016) }\end{array}\end{array} \quad$ Public financial management & yes \\
\hline
\end{tabular}

Source: Elaborated by the authors.

Box 4 indicates a theoretical dispersion in this group of articles. However, strategic planning stands out by appearing directly and indirectly - in the foundation of models such as the municipal strategic plans. In addition, articles exploring municipal planning resort to classic definitions of planning applied at the municipal level. The articles converge, assuming that planning is an instrument that allows managing social change. Planning, in this context, is an intentional and deliberate process of building objectives and instruments for action in order to improve the quality of life in society, and social participation is usually appreciated.

The research revealed the little use of Carlos Matus' model of Situational Strategic Planning. It is a government planning model created specifically to deal with the structures and dynamics that prevail in the states. The articles use, in general, methods 
and instruments inspired in the private sector. The theoretical references presented are not used for data analysis. Therefore, the results of the studies are essentially descriptive, and the models and instruments appear as recommendations. In other words, there is a normative bias, and the most valued parameter comes from strategic planning.

The study also observed whether the articles presented the context of planning in Brazilian municipalities. Three of them did not present this debate. In the others, the discussion is portrayed in two ways: normative context, highlighting the laws on planning; and historical context, focusing on the history of the municipalities in the face of changes in their status after the 1988 Federal Constitution. The two approaches appear interconnected, the first being the most recurrent. Therefore, the analyzes on municipal planning are strongly based on the objectives and forms defined by norms and regulations. This finding strengthens the argument of the prevalence of a normative approach in the articles, rather than a bottom-up approach. In other words, the studies focus on the rules, and the municipalities are faced as instances that enforce them.

Finally, the results of the studies show three lines of conclusions. Three studies highlighted positive aspects of the observed processes. In the words of the authors:

[...] it appears that the PEP approach [Participatory Strategic Planning] [...], applied in the municipality of Doutor Pedrinho was feasible, reaching - even though partially - the main objectives proposed (SOUZA, 1999, p. 28).

The Juiz de Fora Strategic Plan has been in force for more than one term and was able to contribute to the re-election of the mayor who promoted it, [...]. [...]. The 'Plano JF' represented a moment of reflection for the city, where heterogeneous actors discussed common problems. The 'Plano JF' led the municipality to expand its capacity for action, presenting an alternative for the usual answer 'there is no money' (OLIVEIRA, OLIVEIRA, SIQUEIRA et al., 2006, p. 15).

[the study observed] that Brazil has never appreciated people's participation in processes of government planning as much as it has in recent years [...]. The research managed to answer the question raised, observing that Union, states, and municipalities, are adopting dynamic forms of dealing with the Participatory Multi-Year Plans (PPP) in their administration, improving public management [...] (FERREIRA FILHO, 2016, p. 158-159).

A second line of results emerged in two propositional studies, which advocate the relevance and effectiveness of the recommended planning and management models:

One of the objectives of this article was to propose forms of integration between PPAM [municipality's multi-year plan] and PEM [municipality's strategic plan]. Two models with their respective variables were presented, proving the proposed integration. [...]. The second objective of this article was to demonstrate the relationship between the PPAM and PEM in a municipality in Paraná. The case study corroborates the need and the feasibility of integrating these plans through the relationships described in the research protocol designed (REZENDE, 2010, p. 115).

The feasibility of implementing this model in several municipalities, [...], lies in the constructs' flexibility and modulation. The model's design allows meeting the specific needs and priorities of each local government. In addition, the various customizations observed may be based on concepts from the private sector - used as a reference to build the proposed model. Market competitiveness impels organizations to more effective practices, which should also be adopted in public administration (LEITE and REZENDE, 2010, p. 490).

The third line of conclusions emerges from three articles that focus on diagnosing planning processes. They point to the constraints and limitations that influenced the local governments' planning performance:

[...] in the majority in the small municipalities (particularly in the State of Sergipe) planning is quite incipient, restricted to the preparation of the PPA, LDO, and LOA. They are produced by consultants or offices dedicated to public accounting, based on templates. [...]. The study also revealed the lack of knowledge - both in the case of mayors and presidents of city councils - about the main instruments of municipal planning. [...]. Field research showed that the population's participation in decision-making and management oversight is still developing (MARINHO and JORGE, 2015, p. 139). 
[This research] [...] confirms the hypotheses of a lack of planning culture and low-qualified human resources. However, the hypothesis of resistance to elaborating plans was refuted [...] (RITTER and GRASEL, 2016, p. 276).

[...] the current budget dynamics in the analyzed municipalities, still follows the input-based budget model, with little or no evaluation of the efficiency of the programs, and low use of the physical goals and indicators developed in the budget. Therefore, these municipalities demonstrate a low capacity to assimilate the recent reforms that Brazil has proposed in its PFM [Public Financial Management] cycle. The results show [...] that the public accountant, working at the Financial Secretariat, takes on the responsibility of planning since there is a lack of specific sectors dedicated to this activity. Planning is almost always carried out centrally, with little participation from the other secretariats and departments of the indirect administration. [...]. There was also a low involvement of the local legislative branch in the preparation and approval of the budget [...], as well as low participation of the population in the process. As for external control, failures in the budget's execution have not resulted in disapproving the accounts, which encourages the process's low maturity (AZEVEDO and AQUINO, 2016, p. 74).

Despite the importance of municipalities in the Brazilian federation, their capacities to undertake the expected planning activities, as well as the sources of their difficulties, are practically unknown. There are hypotheses about the lack of capacities, which must be confirmed in order to characterize the main challenges, identify their causes, and build more adjusted and effective means of action.

It is worth mentioning that the analyzed studies use a top-down approach, i.e., they uncritically accept the elements defined in the formal normative structure and seek to evaluate or propose solutions so that such determinations are fulfilled. The paradox emerging from this context can be summarized in the question: How to design tools to enforce such determinations if little is known on how municipalities operate? Apparently, there is still a passive view of municipalities, which may be credited to the cultural remnants of past centralization in Brazil.

Finally, the studies analyzed did not focus on the municipalities, but on the local government's ability to follow general rules. This is also relevant, but it is not a complete view of the phenomenon. In other words, more bottom-up studies are needed on how municipalities work, focusing on local structures and dynamics as a way of understanding how they formulate and implement public policies and standards. Thus, it is possible to observe an opportunity for the development of a research agenda connected with the country's demands.

\section{FINAL CONSIDERATIONS}

This research found that government planning has historically been the attribution and practice of central governments. In Brazil, this scenario changed with democratization and was institutionalized in the 1988 Federal Constitution. The municipalities were recognized as federated entities and took a series of roles regarding public policies and management activities, with the challenge of guaranteeing quality and effectiveness. The activity of planning, in this context, stands out as one of the local government's most important tasks.

The roles assumed by local governments entailed the expansion of knowledge about the structures and dynamics related to the new tasks and practices. However, a few scientific articles on non-sectoral planning practices have addressed the case of Brazilian municipalities. The study did not find enough scientific literature to meet the need to expand the knowledge on planning at the municipal level, and the few articles identified and analyzed did not use the same theories or methodologies. The findings indicate that a scientific community in this area of studies has yet to be formed or strengthened.

Future research should, therefore, investigate the directions of planning in the municipalities, in addition to formal normative meanings. Another suggestion for future studies is to explore how to integrate the different sectoral plans in order to produce the PPA. The great heterogeneity of municipalities in Brazil should be considered, as well as how these differences are expressed in the planning processes. 


\section{REFERENCES}

ABRUCIO, F. L. A coordenação federativa no Brasil: a experiência do período FHC e os desafios do governo Lula. Revista de Sociologia e Política, n. 24, p. 41-67, jun. 2005.

ALMEIDA, M. H. T. Recentralizando a federação? Revista de Sociologia e Política, n. 24, p. 29-40, jun. 2005.

ARRETCHE, M. Políticas sociais no Brasil: descentralização em um Estado federativo. Revista Brasileira de Ciências Sociais, v. 14, n. 40, p. 111-141, 1999.

ARRETCHE, M. Democracia, Federalismo e Centralização no Brasil. Rio de Janeiro: Fiocruz /FGV, 2012.

ARRETCHE, M.; MARQUES, E. Municipalização da saúde no Brasil: diferenças regionais, poder do voto e estratégias de governo. Ciência \& Saúde Coletiva, v. 7, n. 3, p. 455-479, 2002.

AZEVEDO, R.; AQUINO, A. O planejamento em municípios de pequeno porte em São Paulo. Revista de Contabilidade e Organizações, v. 10, n. 26, p. 63-76, 2016.

BRASIL. Decreto-lei no 200, de 25 de fevereiro de 1967. Dispõe sobre a organização da Administração Federal, estabelece diretrizes para a Reforma Administrativa e dá outras providências. Brasília, 07 dez. 1966. Available at: <http://www.planalto.gov.br/ccivil_03/DecretoLei/Del0200.htm>. Accessed on: Oct. 06, 2018.

BRASIL. Lei $\mathbf{n}^{\circ} \mathbf{1 1 . 4 4 5}$, de 5 de janeiro de 2007. Estabelece diretrizes nacionais para o saneamento básico. Available at: <http://www. planalto.gov.br/ccivil_03/_Ato2007-2010/2010/Lei/L12305.htm>. Accessed on: Nov. 03, 2018.

BRASIL. Lei no. 10.257, de 10 de julho de 2001. Regulamenta os arts. 182 e 183 da Constituição Federal estabelece diretrizes gerais da política urbana e dá outras providências. Diário Oficial da União. Brasília, DF: Imprensa Oficial, 2001. Available at: <http://www. planalto.gov.br/ccivil_03/leis/LEIS_2001/L10257.htm>. Accessed on: Nov. 03, 2018.

BRASIL. Lei № 12.305, de 2 agosto de 2010. Institui a Política Nacional de Resíduos Sólidos. Available at: <http://www. planalto. gov.br/ccivil_03/_ato2007-2010/2010/lei/l12305.htm>. Accessed on: Nov. $03,2018$.

CARDOSO JUNIOR, J. C. Planejamento Governamental e Gestão Pública no Brasil: elementos para ressignificar o debate e capacitar o estado. Brasília: Ipea, 2011.

CARDOSO JUNIOR, J. C.; SANTOS, E. A. V. Planejamento governamental e aparato burocrático no governo federal brasileiro: disjuntivas críticas e baixo desempenho institucional - questões para uma agenda de pesquisa e intervenção. In: PIRES, R.; LOTTA, G.; OLIVEIRA, V. E. (Orgs.). Burocracia e políticas públicas no Brasil: interseções analíticas. Brasília: Ipea: Enap, 2018. p. 328-253.

CAVALCANTE, P. Descentralização de políticas públicas sob a ótica neoinstitucional: uma revisão de literatura. Revista de Administração Pública, Rio de Janeiro, v. 45, n. 6, p. 1781-1804, 2011.

COUTO, L. F.; MAGALHÃES, A. Iniciativas, funções e estruturas de planejamento federal. Boletim de Análise Político-Institucional, n. 12, jul.-dez. 2017. Brasília: IPEA, 2017. p. 37-42.
DOWBOR, L. Governabilidade e descentralização. Revista do Serviço Público, v. 45, n. 1, p. 95-117, 2015.

DUARTE, L. S. et al. Regionalização da saúde no Brasil: uma perspectiva de análise. Saúde e Sociedade, v. 24, n. 2, p. 472-485, 2015.

EVANS, P. Autonomia e Parceria: Estados e transformação industrial. Rio de Janeiro: UFRJ, 2004.

FALLETI, T. Efeitos da descentralização nas relações intergovernamentais: o Brasil em perspectiva comparada. Sociologias, v. 8, n. 16, p. 46-85, 2006.

FERREIRA FILHO, W. R. A importância do plano plurianual participativo na gestão pública. Revista Controle: Doutrinas e artigos, v. 12, n. 2, p. 147-164, 2016.

FIRJAN. Criação de Municípios: mais impostos e menos serviços à população. Rio de Janeiro: FIRJAN, 2018. Available at: <https://www. firjan.com.br/>. Accessed on: Sept. 06, 2018.

FREITAS, L. O. Políticas públicas, descentralização e participação popular. Revista Katálysis, v. 18, n. 1, p. 113-122, 2015.

GIBSON, E. L.; FALLETI, T. G. La unidad a palos: Conflicto regional y los orígenes del federalismo argentino. Postdata, n. 12, p. 171204, ago. 2007. Available at: <http://www.scielo.org.ar/scielo. php?script=sci_arttext\&pid=S1851-96012007000100008\&lng=es\& nrm=iso>. Accessed on: Sept. 06, 2018.

GOULART, J. O processo Constituinte e Arranjo federativo. Lua Nova, n. 88, p. 185-215, 2013.

GRIN, E. J. Trajetória e avaliação dos programas federais brasileiros voltados a promover a eficiência administrativa e fiscal dos municípios. Revista de Administração Pública, Rio de Janeiro, v. 48, n. 2, p. 459-480, 2014.

GRIN, E. J.; ABRUCIO, F. L. Quando "feds" e "locals" não falam a mesma língua: uma análise sobre dissonâncias na cooperação federativa. Cadernos EBAPE.BR, Rio de Janeiro, v. 15, n. 3, p. 694-719, 2017.

IBGE/MUNIC. Perfil dos Municípios Brasileiros. Brasília: IBGE, 2015.

LEITE, L. O.; REZENDE, D. A. Modelo de gestão municipal baseado na utilização estratégica de recursos da tecnologia da informação para a gestão governamental: formatação do modelo e avaliação em um município. Revista de Administração Pública, Rio de Janeiro, v. 44, n. 2, p. 459-493, 2010.

LEVAC, D.; COLQUHOUN, H.; O'BRIEN, K. K. Scoping studies: advancing the methodology. Implementation science, v. 5, n. 69, p. 1-9, 2010.

LIMA, L. D. et al. Descentralização e regionalização: dinâmica e condicionantes da implantação do Pacto pela Saúde no Brasil. Ciência \& Saúde Coletiva, v. 17, p. 1903-1914, 2012.

MARENCO, A.; STROHSCHOEN, M. T. B. Abrindo a caixa-preta da gestão municipal: variações no perfil de burocracias governamentais locais. In: MARENCO, A.; NOLL, M. I. (Orgs.). A política, as políticas e os controles: como são governadas as cidades brasileiras. Porto Alegre: Tomo Editorial, p. 31-48, 2018.

MARINHO, A. P.; JORGE, M. A. O planejamento local é mais eficiente? Uma análise de 14 municípios sergipanos de pequeno porte. Nova Economia, v. 25, n. 1, p. 123-142, 2015. 
Government planning in Brazilian municipalities: towards a research agenda
Luciana Leite Lima | Lizandro Lui Gianna Vargas Reis Salgado Dias | Luciana Pazini Papi Diogo Joel Demarco
NOLL, M. I.; MARENCO, A. O que sabemos e o que ainda não sabemos sobre política municipal? In: MARENCO, A.; NOLL, M. I. (Orgs.). A política, as políticas e os controles: como são governadas as cidades brasileiras. Porto Alegre: Tomo Editorial, 2018. p. 11-30.

OLIVEIRA, V. C. S. et al. Inovação gerencial em municípios: análise exploratória das práticas de gestão do plano estratégico de Juiz de Fora. Cadernos EBAPE.BR, Rio de Janeiro, v. 4, n. 4, p. 2-17, 2006.

REZENDE, D. A. Integração do Plano Plurianual Municipal e o Planejamento Estratégico Municipal: proposta e experiência de um município paranaense. REDES: Revista do Desenvolvimento Regional, v. 15, n. 2 , p. 92-119, 2010.

REZENDE, F. Planejamento no Brasil: auge, declínio e caminhos para a reconstrução. In: CARDOSO JUNIOR, J. C. A reinvenção do planejamento governamental no Brasil. 4. ed. Brasília: Ipea, 2011. p. 177-237.

RITTER, E. O.; GRASEL, D. Estratégias para a busca da gestão de excelência: um estudo de caso no município de Canarana. Revista de Estudos Sociais, v. 18, n. 36, p. 251-279, 2016.

SADDI, F.C. Política e economia no federalismo do governo Geisel. Revista de Economia Política, v. 23, n. 2, p. 90, 2003.

SÁTYRO, N. G. D.; CUNHA, E. S. M.; CAMPOS, J. Análise espacial da burocracia da assistência social nos municípios brasileiros: notas para uma reflexão sobre a capacidade de implementação dessa política. Opinião Pública, v. 22, n. 2, p. 286-317, 2016.

SCHAEFER, R. et al. Políticas de Saúde de adolescentes e jovens no contexto luso-brasileiro: especificidades e aproximações. Ciência \& Saúde Coletiva, v. 23, n. 9, p. 2849-2858, Sept. 2018.

SOUZA, A. R. Avaliação do processo de implantação de um plano estratégico participativo municipal: um estudo de caso. Revista de Estudos Sociais, v. 1, n. 1, p. 7-30, 1999.

SOUZA, C. Intermediação de interesses regionais no brasil: o impacto do federalismo e da descentralização. Dados, v. 41, n. 3, p. 569$592,1998$.

SOUZA, C. Governos locais e gestão de políticas sociais universais. São Paulo Perspectiva, São Paulo, v. 18, n. 2, p. 27-41, jun. 2004. Available at: <http://www.scielo.br/scielo.php?script=sci_arttext\&pid=S0102$88392004000200004 \&$ Ing=en\&nrm=iso >. Accessed on: June 30, 2019.

TOMIO, F. R. L. A criação de municípios após a Constituição de 1988. Revista Brasileira de Ciências Sociais, v. 17, n. 48, p. 61-69, 2002.

TOMIO, F. R. L. Federalismo, municípios e decisões legislativas: a criação de municípios no Rio Grande do Sul. Revista de Sociologia e Política, n. 24, p. 123-148, 2005.

Luciana Leite Lima

ORCID: https://orcid.org/0000-0002-8761-4114

PhD in social sciences from the State University of Campinas (Unicamp); Associate Professor at the Federal University of Rio Grande do Sul (UFRGS), Porto Alegre-RS, Brazil. E-mail: lucianaleitelima@gmail.com

Lizandro Lui

ORCID: https://orcid.org/0000-0002-9276-247X

PhD in sociology from the Federal University of Rio Grande do Sul (UFRGS); Researcher at the Institute of Applied Economic Research (IPEA), Brasília

- DF, Brazil. E-mail: lizandrolui@gmail.com

Gianna Vargas Reis Salgado Dias

ORCID: https://orcid.org/0000-0001-5075-4546

Master in public policy from the Federal University of Rio Grande do Sul (UFRGS); Researcher at the Center for Research in Municipal Management (Nupegem) at the Federal University of Rio Grande do Sul (UFRGS), Porto Alegre- RS, Brazil. E-mail: gvargasreis@gmail.com

Luciana Pazini Papi

ORCID: https://orcid.org/0000-0002-9112-3967

PhD in political science from the Federal University of Rio Grande do Sul (UFRGS); Adjunct Professor at the Federal University of Rio Grande do Sul (UFRGS), Porto Alegre-RS, Brazil. E-mail: luppapi@yahoo.com.br

Diogo Joel Demarco

ORCID: https://orcid.org/0000-0002-8327-321X

PhD in education from the University of São Paulo (USP); Associate Professor at the Federal University of Rio Grande do Sul (UFRGS), Porto Alegre- RS, Brazil. E-mail: diogo.demarco@ufrgs.br 